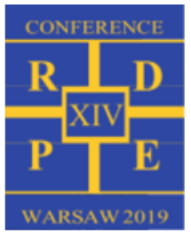

\title{
Analysis of offshore wind farm located on Baltic Sea
}

\author{
A nna Sobotka ${ }^{1}, K_{\text {Kjetan Chmielewski }}{ }^{2}$ M arcin Rowicki ${ }^{3}$, Justyna Dudzińska ${ }^{4}$, Przemysław Janiak ${ }^{5}$, Krzysztof B adyda $^{6}$ \\ ${ }^{1}$ Institute of H eat Engineering, W arsaw U niversity of Technology, Power Generation Strategic A nalysis Department, PKN ORLEN, \\ anna.sobotka@orlen.pl, Poland \\ 2 Power G eneration Strategic A nalysis Department, PK N ORLEN, kajetan.chmielewski@orlen.pl, Poland \\ 3 Power Generation Strategic A nalysis Department, PKN ORLEN, marcin.rowicki@orlen.pl, Poland \\ 4 Power Generation Strategic A nalysis Department, PK N ORLEN, justyna.dudzinska@ orlen.pl, Poland \\ 5 Power Generation Strategic A nalysis Department, PKN ORLEN, przemyslaw.janiak@orlen.pl, Poland \\ ${ }^{6}$ Institute of Heat Engineering, W arsaw U niversity of Technology, krzysztof.badyda@itc.pw.edu.pl, Poland
}

\begin{abstract}
Poland is currently at the beginning of the energy transformation. Nowadays, most of the electricity generated in Poland comes from coal combustion. However, in accordance to the European Union policy of reducing the emission of carbon dioxide to the atmosphere, there are already plans to switch to low-emission energy sources in Poland, one of which are offshore wind farms. The article presents the current regulatory environment of the offshore wind energy in Poland, along with a reference to Polish and European decarbonisation plans. In the further part of the article, the methods of determining the kinetic energy of wind and the power curve of a wind turbine are discussed. Then, on the basis of historical data of wind speeds collected in the area of the Baltic Sea, calculations are carried out leading to obtain statistical distributions of power that could be generated by an exemplary wind farm with a power capacity of 400 M W, located at the place of wind measurements. On their basis, statistical differences in the wind power generation between years, months of the year and hours of the day are analysed.
\end{abstract}

\section{Introduction}

Electricity production in Poland amounted to $165.3 \mathrm{TW} \mathrm{h}$ in 2018 , of which approximately $79.5 \%$ was generated by coal-fired power plants [1]. In this regard, Poland is a black spot on the map of Europe. Due to the environmental requirements related to the climate policy of the European Union, which have been getting stricter for years, Poland faces the requirement to diversify its energy mix and transform its economy towards climate neutrality. On the other hand, it creates an opportunity for the development of other technologies, mainly Renewable Energy Sources (hereinafter referred to as RES). The example of the offshore wind farms fits into the policy of energy changes in the world. Their main advantages are the zero emission of pollutants and greenhouse gases to the atmosphere and the lack of waste generated in the process of their exploitation. Compared to photovoltaics or windmills on land, offshore wind farms have much higher coefficient of capacity utilisation per year. Furthermore, there are social benefits, such as support for the local labour market and entrepreneurs. From an economic point of view, the development of technology and additional revenues to the budgets of local governments can be remarkable. Cooperation with Polish companies in the area of supply chain management also drives the national economy. According to Polish Wind Energy A ssociation (PWEA) estimations [2], by 2030 Poland will have installed additional $6 \mathrm{GW}$ of generation capacity in offshore wind farms. This is a milestone that will allow to diversify generation sources to a large extent. In the
Offshore Wind Farms (hereinafter referred to as OWF) construction projects are involved such companies as PGE, Polenergia and PKN Orlen, which proves the relevant potential of the Baltic Sea. The development plan for maritime areas lists about 2.3 thousand square kilometres of the sea area designated for wind farms, which translates into a potential of 10-12 GW [2]. These are the generation capacities which cannot be passed indifferently, not only due to the ongoing energy transformation forced by the global warming, but also due to the termination of lifetime of ageing conventional units, which will have to be replaced in the near future.

In the article, selected regulatory aspects that appear in discussions about the RES development, including the OWF, have been developed. The methodology of wind power analysis has been discussed, along with the results for an exemplary wind farm located in the B altic Sea.

The aim of the article is to discuss the wind potential of the Exclusive Economic Zone of Poland and to present recommendations concerning the OWF that could be installed there.

\section{Regulatory and market environment}

At present, in Poland there are no generation units located at sea. The Act on renewable energy sources [3], which exists in Polish law, regulate the issue of the OW F only to a very limited extent, which causes uncertainty among investors. There is a plan of adoption of a completely new act on the development of the OWF, which would take probably about a year to implement. 
However, there are regulations that impose restrictions as to the locations where the OWF could be established in the future. In the Act on maritime areas of the Republic of Poland and maritime administration [4] A rticle 23 paragraph $1 a$ is stated that the construction and use of wind power plants in the internal waters and territorial sea is prohibited. This area includes a strip of waters which is 12 nautical miles wide from the coastline. This effectively results in the fact that an Exclusive Economic Zone remains the only free space for wind farm locations.

A nother document limiting the available areas is the Spatial Development Plan of the Polish M aritime Areas [5]. Only 8 of the 93 sea areas mentioned in the document are intended for the development of renewable technologies. The total area of these water bodies is 2342 square kilometres. Additional restrictions result from taking into account the impact of the OWF on the environment in the area of the Exclusive Economic Zone. The key issue here is finding the solution to raise constructions in way that would not endanger the ecological functions of spawning grounds and survival of early stages of fish (roe and larvae) of commecrial species. For each investment, before issuing a building permit, it is recommended to develop rules of conducting fishing in the area of offshore wind farms. For some of the 8 areas, it is recommended to plan RES investments to enable the marking of a transport corridor for units up to 150 meters in length. A II this means that the assumed area of approximately 2.3 thousand square kilometres may be reduced by several hundred square kilometres, which will directly translate into the reduction of the potential OWF capacity in Poland. In the Baltic Sea, at the time of writing the article, permits to build artificial islands were issued for the construction of farms with a maximum capacity of approx. 7,1 [6] GW, mainly in the areas of Ławica Stupska and Ławica Środkowa. This results in the need to plan the development of wind farms and their integration into the national power system so that they bring the greatest possible benefits to the Polish power system and the whole economy.

The OWF management requires forecasting of their operation in advance, as wind sources are uncontrolled. They generate electricity depending on wind changing conditions and the generation from conventional and controllable sources (coal, gas or water) must be adjusted to them in order to balance the supply and demand for energy.

In Europe, according to a report of WindE urope, at the end of 2018 about $189 \mathrm{GW}$ was installed in wind farms (170 GW in onshore and $19 \mathrm{GW}$ in offshore), which produced $14 \%$ of the electricity consumed in the European Union [7]. According to the data of W indE urope, more than $2 / 3$ of wind power is installed in 5 countries: Germany, Spain, Great B ritain, France and Italy. In Poland, according to Polskie Sieci Elektroenergetyczne (PSE) data, at the end of 2018 the installed capacity of wind farms was about $5.8 \mathrm{GW}$ [8], of which onshore wind farms represented $100 \%$. However, their development was inhibited by the socalled «distance act», which prohibits the construction of a wind turbine at a distance smaller than $10 \mathrm{~km}$ from the nearest residential buildings. Newertheless, the development of RES, including wind farms, is suggested by published domestic and foreign documents. According to both the draft of National Energy Policy until 2040 published in November 2019 [9] and the draft of National Energy and Climate Plan for 2021-2030 [10], sent to the European Commission in January 2019, a dynamic development of RES is projected in Poland. These plans include onshore and offshore wind farms. B oth documents, despite the discrepancies in data (which should be unified in their final versions), indicate a clear trend to be followed by the Polish power industry in the coming years. Development works are also progressing in the companies holding concessions for the construction of the OWF, even though there is still regulatory uncertainty.

\section{Analysis of wind power potential}

In this chapter the formulas for calculating the kinetic energy of wind have been derived, which can be easily translated into power generated by the turbine. It is also explained why a power curve was used for the analysis presented in the article. Finally, the potential of wind power for an exemplary wind farm located in the Baltic Sea has been discussed.

The source of wind speed data was FINO database [11], which provides free of charge measurements from the station located in the B altic Sea. Data are collected at an altitude of 102 metres, which enables a realistic representation of the potential capacity of a wind turbine installed at this location. The frequency of data recording is 10 minutes, which introduces a measurement error due to fluctuations of wind power in a given range. Prepared calculation model uses the hourly value of speed, which is the average of measurements in a given hour. The wind power analysis was based on data from January 1 , 2010 to June 30, 2019.

The kinetic energy carried by wind can be written with a following formula, in which „m” is the mass and „V" is its speed.

$$
\varepsilon_{K}=\frac{1}{2} \cdot m \cdot V^{2}
$$

By substituting „m” with the expression

$$
m=\rho \cdot v
$$

where , $\rho "$ is the density, while , $v$ " is the volume of air, equation (1) takes the form of

$$
\varepsilon_{K}=\frac{1}{2} \cdot \rho \cdot v \cdot V^{2}
$$

By substituting , $v$ " with the expression

$$
\mathrm{v}=\mathrm{V} \cdot \mathrm{A}
$$

where ,A" is the rotor cross-section, equation (3) takes the form of

$$
P=\frac{1}{2} \cdot \rho \cdot A \cdot V^{3}
$$


This formula allows to determine the power curve of a wind turbine, assuming that there are no losses resulting from the conversion of wind kinetic energy into electricity. It also assumes that a turbine generates electricity even at a wind speed not much higher than zero, which does not translate into reality. Turbine manufacturers provide their own power curves for each type of the wind turbine. This allows to determine the level of power generated with better accuracy depending on the speed of the wind stream flowing through the rotor blades. For the purpose of the article, a turbine power curve based on V164 - 8 M W model data from Vestas [12] was used. Data of power output in dependance of wind speed was presented in Table 1.

Tab.1. Power curve based on V 164 - 8 M W V estas [8]

\begin{tabular}{|c|c|}
\hline $\begin{array}{c}\text { Wind speed } \\
{[\mathrm{m} / \mathrm{s}]}\end{array}$ & Power [kW ] \\
\hline 4 & 110 \\
\hline 4,5 & 350 \\
\hline 5 & 600 \\
\hline 5,5 & 850 \\
\hline 6 & 1140 \\
\hline 6,5 & 1490 \\
\hline 7 & 1900 \\
\hline 7,5 & 2370 \\
\hline 8 & 2900 \\
\hline 8,5 & 3500 \\
\hline 9 & 4155 \\
\hline 9,5 & 4870 \\
\hline 10 & 5630 \\
\hline 10,5 & 6420 \\
\hline 11 & 7150 \\
\hline 11,5 & 7610 \\
\hline 12 & 7865 \\
\hline 12,5 & 7940 \\
\hline 13 & 7970 \\
\hline 13,5 & 8000 \\
\hline 14 & 8000 \\
\hline 14,5 & 8000 \\
\hline 15 & 8000 \\
\hline 15,5 & 8000 \\
\hline 16 & 8000 \\
\hline 16,5 & 8000 \\
\hline 17 & 8000 \\
\hline 17,5 & 8000 \\
\hline 18 & 8000 \\
\hline 18,5 & 8000 \\
\hline 19 & 8000 \\
\hline 19,5 & 8000 \\
\hline 20 & 8000 \\
\hline 20,5 & 8000 \\
\hline 21 & 8000 \\
\hline 21,5 & 8000 \\
\hline 22 & 8000 \\
\hline 22,5 & 8000 \\
\hline 23 & 8000 \\
\hline 23,5 & 8000 \\
\hline 24 & 8000 \\
\hline 24,5 & 8000 \\
\hline 25 & 8000 \\
\hline
\end{tabular}

In order to conduct an in-depth analysis of wind data, an example of a $400 \mathrm{M} \mathrm{W}$ wind farm consisting of 50 wind turbines was taken into account. The calculation model assumes transmission losses at the level of $4 \%$ of the generated power, $100 \%$ of availability, lack of losses caused by the possible turbulent wind flow and lack of wake losses.

The results of the analysis are presented in the form of average power generated by the farm in hourly and monthly cross-section. Besides there are calculated percentiles referring to the percentage of time while the amount of generated power did not fall below a given percentage of the sample.

\section{Results}

On the basis of the calculations carried out, statistical power distributions are obtained for a $400 \mathrm{M} \mathrm{W}$ offshore wind farm located in the Baltic Sea at the wind speed measurement site. This chapter presents selected results.Conditional formatting in the form of a gradient of three colours: red, yellow and green has been applied to facilitate the reception of the analysis results presented in the following tables. If the value of the OWF power is relaively small, it is displayed on a green background, if the value is large, the background is red.

Tab.2. A verage power generation of $400 \mathrm{M} \mathrm{W}$ OWF in a given hour for the years 2010-2019

\begin{tabular}{|c|c|}
\hline Hour & Power [M W] \\
\hline $00: 00$ & 255,92 \\
\hline $01: 00$ & 202,73 \\
\hline $02: 00$ & 206,56 \\
\hline $03: 00$ & 205,40 \\
\hline $04: 00$ & 205,61 \\
\hline $05: 00$ & 207,10 \\
\hline $06: 00$ & 205,88 \\
\hline $07: 00$ & 204,60 \\
\hline $08: 00$ & 202,94 \\
\hline $09: 00$ & 202,45 \\
\hline $10: 00$ & 201,72 \\
\hline $11: 00$ & 201,12 \\
\hline $12: 00$ & 204,31 \\
\hline $13: 00$ & 205,37 \\
\hline $14: 00$ & 207,46 \\
\hline $15: 00$ & 209,31 \\
\hline $16: 00$ & 210,00 \\
\hline $17: 00$ & 213,45 \\
\hline $18: 00$ & 215,90 \\
\hline $19: 00$ & 215,88 \\
\hline $20: 00$ & 217,14 \\
\hline $21: 00$ & 214,39 \\
\hline $22: 00$ & 216,59 \\
\hline $23: 00$ & 212,04 \\
\hline & \\
\hline
\end{tabular}


Tab.3. A verage power generation of $400 \mathrm{M} \mathrm{W} \mathrm{OWF} \mathrm{in} \mathrm{a} \mathrm{given}$ month for the years 2010-2019

\begin{tabular}{|c|c|}
\hline M onth & Power [M W ] \\
\hline January & 243,95 \\
\hline February & 235,21 \\
\hline M arch & 228,02 \\
\hline A pril & 214,46 \\
\hline M ay & 182,33 \\
\hline June & 173,39 \\
\hline July & 163,12 \\
\hline A ugust & 166,84 \\
\hline September & 191,37 \\
\hline October & 247,31 \\
\hline N ovember & 223,70 \\
\hline December & 257,43 \\
\hline
\end{tabular}

Table 2. shows that the average capacity of the calculated farm for the data from the whole period under consideration is higher in the afternoon and night hours. W hat is interesting, however, these are not so significant differences - they are within the range of less than 14\% of the installed capacity. The differences in months, shown in Table 3, are much clearer, and the difference between the minimum (July) and maximum (December) is as much as $24 \%$ of the installed capacity.

The coefficient of installed capacity utilisation ${ }, C_{p}$ " has al so been calculated. It was calculated as the quotient of the produced energy , $E$ " in a given period and the product of the installed power,$P_{N}$ " and the examined period ,T". It allows to compare the power of the OW F with other RES or conventional ones.

$$
C_{p}=\frac{E}{P_{n} \cdot T}
$$

Tab.5. Percentiles of power distribution in individual hours on average for the years 2010-2019
For the whole analysed period, the coefficient of installed capacity utilisation amounted to $48.98 \%$, which is comparable to the data available in the literature [2]. Compared to other RES: onshore wind farms and photovoltaics, calculated coefficient of installed capacity utilisation is much higher. For modern onshore wind farms the coefficient is around $40 \%$, while for photovoltaics it is only about $10 \%$ [2]. The partial results for individual years are presented in Table 4. They show how much the wind power differs from one year to the next. This is very important especially because it is a value over which the investor or operator has no influence.

Tab.4. Coefficient of utilisation of installed capacity in a given year for the full years 2010-2018

\begin{tabular}{|c|c|}
\hline Y ear & Capacity factor [\%] \\
\hline 2010 & $52,67 \%$ \\
\hline 2011 & $53,69 \%$ \\
\hline 2012 & $52,23 \%$ \\
\hline 2013 & $50,49 \%$ \\
\hline 2014 & $52,74 \%$ \\
\hline 2015 & $49,85 \%$ \\
\hline 2016 & $39,41 \%$ \\
\hline 2017 & $48,64 \%$ \\
\hline 2018 & $40,08 \%$ \\
\hline
\end{tabular}

In case of division of the generated power in 24 hours into individual percentiles of occurrence, as shown in Table 5, it can be clearly noticed that (according to the methodology described earlier and the wind data used) for $20 \%$ of time in a year the OWF works with $100 \%$ power, while for $10 \%$ of the time the OWF does not produce anything. It is also worth noting that hours without electricity production occur at any moment of the day, which clearly shows how important is to secure generation in controllable power plants for the efficient and uninterrupted operation of the electricity system.

\begin{tabular}{|c|c|c|c|c|c|c|c|c|c|c|c|c|c|c|c|c|c|c|c|}
\hline \multicolumn{20}{|c|}{ Percentile } \\
\hline & 0,95 & 0,90 & 0,85 & 0,80 & 0,75 & 0,70 & 0,65 & 0,60 & 0,55 & 0,50 & 0,45 & 0,40 & 0,35 & 0,30 & 0,25 & 0,20 & 0,15 & 0,10 & 0,05 \\
\hline 00:00 & 384 & 384 & 384 & 384 & 380 & 367 & 340 & 295 & 248 & 205 & 168 & 131 & 100 & 74 & 55 & 36 & 20 & 0 & 0 \\
\hline 01:00 & 384 & 384 & 384 & 384 & 379 & 364 & 335 & 296 & 249 & 199 & 160 & 128 & 95 & 72 & 53 & 35 & 18 & 0 & 0 \\
\hline 02:00 & 384 & 384 & 384 & 384 & 379 & 364 & 335 & 283 & 241 & 200 & 160 & 123 & 92 & 69 & 52 & 35 & 18 & 0 & 0 \\
\hline 03:00 & 384 & 384 & 384 & 384 & 380 & 364 & 333 & 290 & 242 & 198 & 157 & 121 & 94 & 70 & 50 & 33 & 16 & 0 & 0 \\
\hline 04:00 & 384 & 384 & 384 & 384 & 377 & 362 & 331 & 292 & 247 & 200 & 162 & 120 & 91 & 68 & 50 & 33 & 16 & 0 & 0 \\
\hline 05:00 & 384 & 384 & 384 & 384 & 378 & 364 & 339 & 295 & 246 & 200 & 161 & 122 & 94 & 69 & 50 & 33 & 16 & 0 & 0 \\
\hline $06: 00$ & 384 & 384 & 384 & 384 & 378 & 362 & 336 & 295 & 243 & 199 & 156 & 122 & 92 & 68 & 48 & 31 & 16 & 0 & 0 \\
\hline 07:00 & 384 & 384 & 384 & 384 & 380 & 363 & 332 & 290 & 239 & 198 & 153 & 119 & 91 & 67 & 46 & 32 & 16 & 0 & 0 \\
\hline 08:00 & 384 & 384 & 384 & 384 & 380 & 364 & 334 & 291 & 242 & 194 & 151 & 113 & 86 & 64 & 45 & 29 & 14 & 0 & 0 \\
\hline 09:00 & 384 & 384 & 384 & 384 & 380 & 366 & 339 & 287 & 238 & 184 & 141 & 109 & 86 & 62 & 44 & 30 & 11 & 0 & 0 \\
\hline $10: 00$ & 384 & 384 & 384 & 384 & 380 & 365 & 337 & 289 & 235 & 189 & 147 & 112 & 84 & 62 & 42 & 26 & 9 & 0 & 0 \\
\hline 11:00 & 384 & 384 & 384 & 384 & 380 & 366 & 336 & 289 & 239 & 192 & 149 & 110 & 81 & 61 & 40 & 22 & 4 & 0 & 0 \\
\hline $12: 00$ & 384 & 384 & 384 & 384 & 382 & 367 & 341 & 288 & 245 & 194 & 149 & 116 & 85 & 60 & 40 & 25 & 6 & 0 & 0 \\
\hline 13:00 & 384 & 384 & 384 & 384 & 382 & 367 & 338 & 291 & 245 & 202 & 159 & 120 & 86 & 62 & 42 & 26 & 8 & 0 & 0 \\
\hline $14: 00$ & 384 & 384 & 384 & 384 & 380 & 368 & 346 & 304 & 252 & 204 & 158 & 120 & 90 & 65 & 45 & 27 & 6 & 0 & 0 \\
\hline $15: 00$ & 384 & 384 & 384 & 384 & 384 & 371 & 350 & 308 & 257 & 211 & 161 & 121 & 92 & 67 & 45 & 28 & 7 & 0 & 0 \\
\hline 16:00 & 384 & 384 & 384 & 384 & 384 & 373 & 356 & 315 & 262 & 210 & 166 & 119 & 89 & 66 & 46 & 31 & 9 & 0 & 0 \\
\hline $17: 00$ & 384 & 384 & 384 & 384 & 384 & 374 & 355 & 320 & 267 & 217 & 167 & 130 & 99 & 72 & 51 & 32 & 14 & 0 & 0 \\
\hline 18:00 & 384 & 384 & 384 & 384 & 384 & 373 & 354 & 313 & 274 & 223 & 173 & 138 & 105 & 76 & 55 & 35 & 17 & 0 & 0 \\
\hline 19:00 & 384 & 384 & 384 & 384 & 384 & 374 & 356 & 319 & 270 & 228 & 180 & 143 & 109 & 80 & 57 & 39 & 18 & 0 & 0 \\
\hline 20:00 & 384 & 384 & 384 & 384 & 384 & 372 & 353 & 317 & 278 & 226 & 181 & 141 & 112 & 81 & 56 & 38 & 20 & 0 & 0 \\
\hline 21:00 & 384 & 384 & 384 & 384 & 383 & 372 & 353 & 318 & 273 & 228 & 185 & 142 & 106 & 80 & 56 & 39 & 22 & 0 & 0 \\
\hline $22: 00$ & 384 & 384 & 384 & 384 & 383 & 369 & 353 & 311 & 263 & 218 & 183 & 141 & 106 & 80 & 59 & 38 & 21 & 0 & 0 \\
\hline $23: 00$ & 384 & 384 & 384 & 384 & 382 & 368 & 346 & 304 & 257 & 216 & 178 & 140 & 105 & 79 & 56 & 39 & 21 & 0 & 0 \\
\hline
\end{tabular}


Based on the power factor coefficients in Table 4, simple calculations can be made to show the scale of changes in power generation for the most and least windy years. In the best case(2011), when $C_{p}=53.69 \%$, power generation could be etsimated at about 4.7 TWh, while in the worst case (2016) $C_{p}$ was only $39.41 \%$, which translates into about $3.45 \mathrm{TW} \mathrm{h}$. These fluctuations have impact directly on the generated profits.Unfortunately, outside the scope of the authors $\odot$ knowledge is the answer to the question whether these are random fluctuations or the announcement of wider changes in the wind power on the Baltic Sea caused by e.g. climate changes. The described trend is also visible in Fig.1., which presents an ordered diagram of the generation of the example OWF per year.

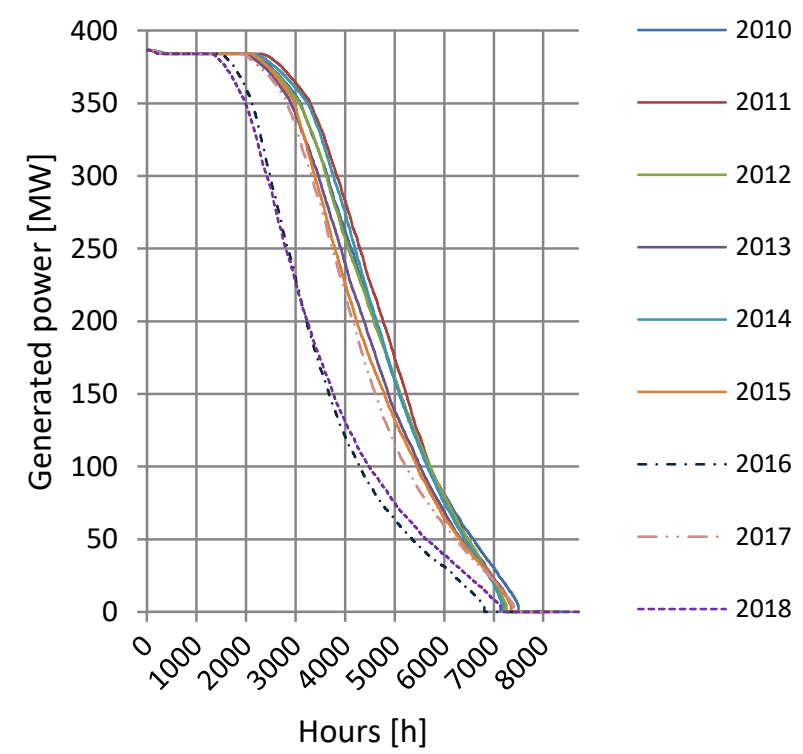

Fig.1. Structured diagram of wind generation in particular years of the analysed period

\section{Summary}

Considerations of selected regulatory aspects that are important in the context of the OWF development in Poland, presented in the article, indicate the lack of clearly defined borders of the areas in the Exclusive Economic Zone of Poland, where the OWF could be established. Possible reduction of this area will translate into a significant reduction of wind power potential. A dditional concerns arise from the lack of adequate legal conditions that would regulate the offshore branch of industry. Nevertheless, the companies holding concessions for the construction of the OWF are progressing with the offshore projects development.

The publicly available wind measurements and the wind turbine power curve enabled performing considerations of power generated by a hypothetical OWF located in the Baltic Sea and changes in the level of this power at different periods of time in the year and during the day.

On the basis of the calculations performed, statistical power distributions were determined. The coefficient of capacity utilisation for the whole analysed period was
$48.98 \%$. Analysis of individual years showed that the most windy year was 2011, when total generation amounted to $4703244 \mathrm{MWh}$, and the least windy year was 2016 with generation of $3452316 \mathrm{MWh}$. These factors have a significant impact on revenue which the OWF could generate each year. It is worth noting, that it is out of a farm's owner control. The distribution of the percentiles clearly illustrates the situation which must be faced. In the analysed period, for $20 \%$ of time, the example OW F operates at 100\% capacity, while for $10 \%$ of time generation is $0 \%$. This clearly shows, that backup with the conventional power plants is necessary to ensure safe and uninterrupted work of the electricity system.

Compared to onshore wind farms and photovoltaics, the OWF generate more electricity from the same installed power. The coefficient of capacity utilisation for offshore wind farms is nearly $25 \%$ higher than the coefficient for the onshore wind farms, and five times higher than for the photovoltaics [2]. This also means, that the OWF generate electricity more steadily than mentioned renewable technologies.

All of this, along with the fact, that the OWF do not disrupt rural areas, truly shows the potential of Baltic Sea in generating clean energy.

\section{References}

[1] Polskie Sieci Elektroenergetyczne S.A. (2018). Zestawienie danych ilościowych dotyczacych funkcjonowania KSE w 2018 roku. Retrieved from https://www.pse.pl/dane-systemowelfunkcjonowanierb/raporty-roczne-z-funkcjonowania-kse-za-rok/raportyza-rok-2018

[2] Polskie Stowarzyszenie Energetyki Wiatrowej (2019). Przyszłość morskiej energetyki wiatrowej $w$ Polsce. Retrieved from http://psew.pl/wpcontent/uploads/2019/06/Przysz $\%$ C5\%820\%C5\%9B\%C 4\%87-morskiej-energetyki-wiatrowej-w-Polsceraport.pdf

[3] Ustawa z dnia 20 lutego 2015 r. o odnawialnych źródtach energii, Dz.U. 2015 poz. 478

[4] Ustawa z dnia 21 marca 1991 r. o obszarach morskich Rzeczypospolitej Polskiej $i$ administracji morskiej, Dz. U. 2019.0.2169

[5] Rozporządzenie Ministra Gospodarki Morskiej i Żeglugi śródlądowej oraz Ministra Inwestycji i Rozwoju Plan zagospodarowania przestrzennego morskich wód wewnętrznych, morza terytorialnego i wytacznej strefy ekonomicznej (Projekt z dnia 22.07.2019 r.)

[6] Polskie Sieci Elektroenergetyczne S.A. (2019). Wykaz Podmiotów ubiegających się o przytaczenie do Krajowej Sieci Przesytowej. Retrieved from https://www.pse.pl/obszary-dzialalnosci/krajowy-system- 
elektroenergetyczny/wykaz-podmiotow-ubiegajacych-sieo-przylaczenie

[7] WindEurope (2019). Wind energy in Europe in 2018. Trends and statistics. Retrived from https://windeurope.org/wp-content/uploads/files/aboutwind/statistics/WindEurope-Annual-Statistics-2018.pdf

[8] Polskie Sieci Elektroenergetyczne S.A. (2019). Informacja o dostępności mocy przytaczeniowej do sieci przesytowej. Retrieved from https://www.pse.pl/danesystemowe/praca-kse/informacje-ogolne/informacja-odostepnosci-mocy-przylaczeniowej

[9] M inisterstwo Energii (2019). Projekt Polityki energetycznej Polski do 2040 roku. Retrived from https://www.gov.pl/web/aktywa-panstwowe/politykaenergetyczna-polski-do-2040-r-zapraszamy-dokonsultacji1

[10] Ministerstwo Energii (2019). Projekt Krajowego planu na rzecz energii i klimatu na lata 2021-2030. Retrived from https://www.gov.pl/attachment/01f5256f$\underline{582 a-47 a 6-b 41 a-42215 e 4 a 76 e 0}$

[11] FIN O-Datenbank (2019). FINO-Datenbank. Retrieved from http://fino.bsh.del

[12] Desmond C., Murphy J., Blonk L., Haans W., Description of an $8 \mathrm{M} \mathrm{W}$ reference wind turbine, Journal of Physics : Conference Series 753:092013, (2016) 